\title{
TERAPI GERAK BAGI PENDERITA STROKE
}

Oleh: Widiyanto

Dosen Jurusan Pendidikan Kesehatan dan Rekreasi FIK UNY

\section{ABSTRAK}

Rehabilitasi stroke merupakan sebuah program komprehensif yang terkoordinasi antara medis dan rehabilitasi dengan tujuan mengoptimalkan dan memodifikasi kemampuan fungsional yang ada. Gejala sisa fungsional yang disebabkan karena defisit motorik merupakan fokus utama program rehabilitasi stroke. Program rehabilitasi stroke sendiri telah terbukti dapat mengoptimalkan pemulihan sehingga penyandang stroke mendapat keluaran fungsional dan kualitas hidup yang lebih baik.

Salah satu program rehabilitasi yang sering dipergunakan untuk mengembalikan fungsi karena defisit motorik adalah program latihan gerak. Dalam teknik ini dilakukan latihan fungsional dan identifikasi kunci utama tugas-tugas motorik. Setiap tugas motorik dianalisis, ditentukan komponen-komponen yang tidak dapat dilakukan, melatih penderita untuk hal-hal tersebut serta memastikan latihan ini dilakukan pada aktivitas sehari-hari pasien. Latihan motorik harus dilakukan dalam bentuk aktivitas fungsional karena tujuan dari rehabilitasi tidak hanya sekedar mengembalikan suatu pergerakan akan tetapi mengembalikan fungsi.

Kata Kunci: Terapi, stroke, gerak.

Stroke merupakan suatu gangguan fungsi saraf akut yang disebabkan oleh karena gangguan peredaran darah otak yang 
timbul secara mendadak, dalam beberapa detik atau secara cepat dalam beberapa jam dengan gejala dan tanda yang sesuai dengan daerah otak yang terganggu.

Delapan puluh persen penderita stroke mempunyai defisit neuromotor sehingga memberikan gejala kelumpuhan sebelah badan dengan tingkat kelemahan bervariasi dari yang lemah hingga berat, kehilangan sensibilitas, kegagalan sistem koordinasi, perubahan pola jalan dan terganggunya keseimbangan. Hal ini mempengaruhi kemampuannya untuk melakukan aktivitas hidup sehari-hari. Oleh karena itu setelah serangan stroke, penderita harus mempelajari kembali hubungan somatosensori baru atau lama untuk melakukan tugas-tugas fungsionalnya.

Rehabilitasi stroke merupakan sebuah program terkoordinasi yang memberikan suatu perawatan restoratif untuk memaksimalkan pemulihan dan meminimalisir impairmen, disabilitas dan handikap yang disebabkan oleh karena stroke. Rehabilitasi stroke telah terbukti dapat mengoptimalkan pemulihan sehingga penyandang stroke mendapat keluaran fungsional dan kualitas hidup yang lebih baik.

Salah satu terapi rehabilitasi yang sering dipergunakan adalah program latihan gerak. Dalam teknik ini dilakukan latihan fungsional dan identifikasi kunci utama suatu tugas-tugas motorik, seperti duduk, berdiri atau berjalan. Setiap tugas motorik dianalisis, ditentukan komponen-komponen yang tidak dapat

MEDIKORA Vol. V, No 1, April 2009: 118-129 
dilakùkan, melatih penderita untuk hal-hal tersebut serta memastikan latihan ini dilakukan pada aktivitas sehari-hari pasien.

Latihan motorik harus dilakukan dalam bentuk aktivitas fungsional karena tujuan dari rehabilitasi tidak hanya sekedar mengembalikan suatu pergerakan akan tetapi juga mengembalikan fungsi. Proses latihan harus meningkatkan kemudahan mobilisasi, rawat diri dan aktivitas kehidupan sehari-hari yang lain bagi penderita stroke.

\section{Konsep Pembelajaran Gerak}

Pembelajaran (learning) merupakan suatu fenomena internal yang tidak dapat secara langsung diamati. Fenomena ini didefinisikan sebagai suatu perubahan permanen dalam kemampuan merespon sebagai akibat latihan atau suatu pengalaman.

Woodson (1995) mendefinisikan kemampuan motor learnirg sebagai kemampuan seseorang untuk belajar dan mengorganisasikan pergerakan dengan tujuan untuk beradaptasi terhadap lingkungannya.

Terdapat perbedaan antara penampilan motorik (motor performance) dan pembelajaran motorik (motor learning). Schmidt (1988) mendefinisikan motor performance sebagai suatu penampilan keterampilan motorik tertentu yang terjadi selama latihan dan tidak bersifat permanen, sementara motor learning adalah keterampilan yang dipertahankan bahkan setelah latihan dihentikan. 
Penelitian-penelitian yang telah dilakukan sebelumnya [Platz et al (1994), Motomura et al (1989)] menemukan bahwa kemampuan untuk mempelajari tugas-tugas motorik setelah stroke dapat berubah, tetapi derajatnya bervariasi tergantung gejala yang diakibatkan oleh stroke. Penderita stroke dengan apraksia akan mempunyai dampak negatif pada proses motor learning, akan tetapi pada penderita stroke dengan hemiparetik ringan proses motor learning hanya sedikit terganggu. .

Konsep motor learning pada penderita stroke mempunyai tujuan :

1. Membantu penderita stroke bergerak dalam aktivitas fungsional dengan pola pergerakan normal.

2. Membantu penderita stroke mencapai suatu pergerakan aktif secara otomatis.

3. Memberikan repetisi sehingga pola normal tingkah laku dapat dipelajari.

4. Melatih penderita stroke dalam sejumlah kondisi yang bervariasi sehingga keterampilan dapat ditransfer pada situasi dan lingkungan yang berbeda-beda.

\section{Tahap Motor Learning}

Tiga tahapan motor learning menurut Fitts dan Posner (1967) 8,9 :

MEDIKORA Vol. V, No 1, April 2009: 118-129 
1. Cognitive stage. Pada tahap ini dibutuhkan pemusatan perhatian dalam memahami tugas-tugas motorik yang akan dilakukan dan strategi untuk melakukannya.

2. Associative stage. Mulai dikembangkan rujukan internal tentang pergerakan motorik yang tepat dalam melakukan suatu tugas motorik, sehingga penderita dapat membandingkan penampilan motoriknya dengan rujukan ini.

3. Autonomous stage. Ditandai dengan atensi minimal pada penampilan motorik. Kemampuan untuk mendeteksi kesalahan telah berkembang penuh dan penampilan motorik bersifat stabil dan otomatis.

\section{Perencaan terapi berdasarkan konsep motor learning}

Beberapa konsep untuk membantu proses intervensi terapeutik berdasarkan prinsip motor learning adalah :

\section{Determinan spesifik dari motor kontrol}

Hal yang dibutuhkan agar program rehabilitasi pasien stroke berhasil adalah penyusunan rencana terapi yang realistik dan memilih strategi intervensi yang tepat dengan memahami mekanisme penyebab timbulnya defisit motorik. Untuk itu perlu dilakukan identifikasi defisit motorik, menentukan komponen kontrol motorik yang abnormal dan menentukan komponen abnormal mana yang merupakan penyebab utama timbulnya defisit motorik. 
Faktor yang mempengaruhi pergerakan normal dapat digambarkan sebagai berikut :

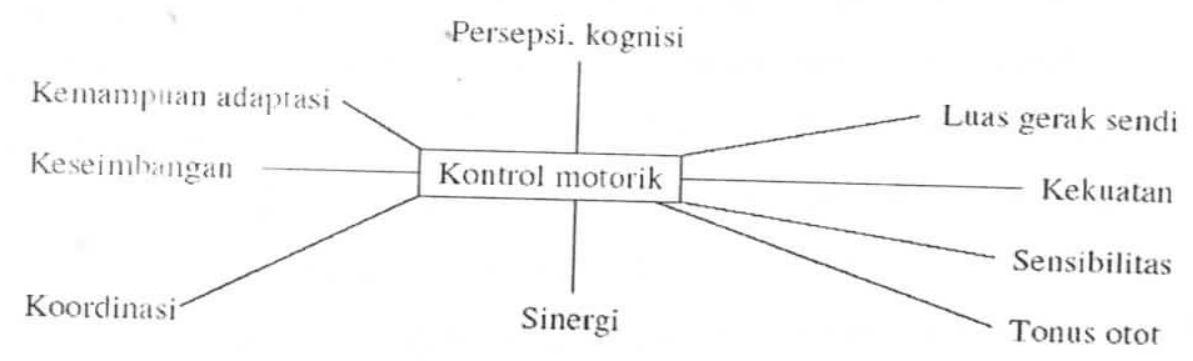

Gambar I. Faktor-faktor yang mempengaruhi pergerakan normal

\section{Umpan balik (feedback)}

Umpan balik merupakan suatu faktor penting yang menurut banyak teori mempengaruhi proses motor learning. Seperti latihan, umpan balik merupakan variabel yang dapat dikontrol dan diubah untuk meningkatkan proses belajar.

Umpan balik adalah suatu informasi tentang suatu respon yang dapat bersifat intrinsik atau ekstrinsik. Umpan balik intrinsik didefinisikan sebagai suatu informasi sensori yang datang dari reseptor khusus di dalam otot, sendi, tendon dan kulit serta reseptor visual dan auditorius baik selama atau setelah dihasilkannya gerakan. Sementara itu umpan balik ekstrinsik adalah informasi dari sumber eksternal tentang gerakan yang diberikan kepada orang yang akan melakukan hal tersebut.

Pada pasien stroke, umpan balik intrinsik sering mengalami distorsi atau bahkan menghilang sehingga efektivitasnya dalam

MEDIKORA Vol. V, No 1, April 2009:' 118-129 
memberikan umpan balik tentang penampilan motorik menjadi terbatas. Hal ini mengakibatkan diperlukannya suatu penguatan melalui umpan balik ekstrinsik yang tepat. Umpan balik ekstrinsik dapat memberikan informasi tambahan untuk memfasilitasi kesadaran dini akan suatu gerakan dan proses belajar. Secara teoritis, umpan balik ekstrinsik merupakan hal penting untuk terbentuknya rujukan internal tentang ketepatan suatu pergerakan, yang terbentuk melalui proses latihan. Hal ini merupakan inti proses motor learning pada penderita stroke. Umpan balik ekstrinsik mempunyai fungsi:

1. Memberikan informasi kepada orang yang akan menggerakan tubuhnya tentang respon keluaran suatu gerakan dan kesalahan yang dibuat olehnya.

2. Sebagai penguat (reinforcement) atau penghargaan (reward) untuk suatu perilaku bila telah mendekati tujuan yang diinginkan.

3. Sebagai suatu motivator sehubungan dengan pencapaian tujuan.

Umpan balik ekstrinsik harus diberikan secara bertahap. Pada awal tahap kognitif (cognitive stage) diperlukan pemberian umpan balik ekstrinsik yang cukup besar, sementara pada tahap asosiasi umpan balik ini mulai dikurangi karena bila hal ini tidak dilakukan maka penderita stroke akan menjadi seseorang yang tidak mandiri dalam melakukan tugas-tugas motoriknya. Umpan balik ekstrinsik bila dipergunakan secara tepat, dapat memfasilitasi perkembangan suatu rujukan internal tentang ketepatan 
pergerakàn. Majsak (1996) berpendapat bahwa jika umpan balik ektrinsik tidak diinternalisasikan mejadi umpan balik intrinsik (rujukan internal), maka tidak akan terjadi suatu perubahan permanen.

\section{Latihan}

Latihan merupakan satu hal yang paling penting pada proses motor learning (Schmidt, 1988). Keterampilan seseorang akan meningkat sesuai dengan jumlah latihan yang diberikan dan dilakukan (Newell \& Rosenbloom, 1981).

\section{Tipe-Tipe Latihan}

\section{a. Massed practice vs Distributed practice}

Schmidt (1998) membedakan antara massed practice dan distributed practice. Pada massed practice, satu sesi latihan terdiri dari waktu latihan yang lebih banyak dari waktu istirahat. Pada distributed practice, satu sesi latihan terdiri dari jumlah waktu latihan yang sama dengan waktu istirahat. Pada pasien stroke distributed practice lebih sesuai untuk diberikan karena kelelahan merupakan suatu faktor keterbatasan umum yang sering terjadi.

\section{b. Variable vs Repetitive Practice}

Variable practice adalah bentuk latihan dengan mempelajari sejumlah variasi dari satu tugas motorik, sementara repetitive practice adalah bentuk latihan berulang yang sama atau konstan untuk suatu tugas motorik. Pada' latihan untuk penderita stroke, variable practice bermanfaat untuk meningkatkan kemampuan transfer keterampilan motorik pada lingkungan yang berbeda,

MEDIKORA Vol. V, No 1, April 2009: 118-129 
sementara suatu repetitive practice bermanfaat untuk memperbaiki penampilan motorik.

\section{c. Blocked Practice vs Random Practice}

Blocked practice adalah suatu teknik latihan dengan cara melakukan satu tùgas hingga menguasainya, kemudian diikuti dengan latihan tugas selanjutnya. Sementara, random practice adalah suatu bentuk latihan dengan cara melakukan latihan secara acak sejumlah tugas atau sejumlah variasi dalam satu tugas motorik sebelum dikuasainya salah satu tugas atau variasi. Secara teoritis, blocked practice lebih menguntungkan untuk proses akuisisi keterampilan yang efisien, sementara random practice lebih efektif untuk proses retensi dan transfer keterampilan motorik.

\section{d. Whole vs Part Practice}

Newell (1981) merekomendasikan bentuk latihan berupa part pratice (latihan dengan memecah suatu tugas motorik menjadi tugas-tugas motorik yang lebih kecil) untuk memperoleh komponen dasar tugas motorik, diikuti dengan melatihnya sebagai suatu kesatuan (whole practice). Masih terdapat perbedaan pendapat mengenai penggunaan kedua jenis latihan ini pada penderita stroke, akan tetapi secara umum jika seorang penderita stroke tidak mampu menguasai seluruh langkah secara simultan, maka dapat diberikan dorongan atau bimbingan manual untuk aspekaspek tertentu dari tugas tersebut. Bantuan terapis dapat kemudian secara bertahap dikurangi pada waktu selanjutnya. 


\section{Tipe-Tipe Tugas Motorik}

Gentile (1972) mempostulasikan bahwa aktivitas motorik dapat diklasifikasikan mejadi 4 kategori umum berdasarkan pada kondisi lingkungan dan metode pengeksekusian tugas-tugas motorik.

Closed tasks adalah aktivitas motorik dalam lingkungan yang stabil/statis (seperti tangga) dan dapat diprediksi serta menggunakan metode aktivitas motorik yang bersifat konsisten sepanjang waktu. Contoh menyisir rambut, karena dibutuhkan pola pergerakan konsisten sepanjang waktu.

Open tasks adalah aktivitas yang membuat pasien harus membuat suatu keputusan adaptif terhadap suatu keadaan yang tidak dapat diprediksi karena objek tidak bersifat statis (bergerak). Oleh karena hal itu maka aktivitas ini memerlukan pergerakan yang tepat waktu dan antisipasi spasial. Dalam kondisi latihan ini dapat dibedakan : a. Consistent motion task. Jika pergerakan objek sudah dapat diprediksi (contoh melangkah ke eskalator). b. Variable motion task. Pergerakan objek dalam lingkungan yang tidak dapat diprediksi, seperti perubahan lingkungan saat melakukan manuver dengan kursi roda listrik. Seseorang harus mempelajari lebih dari satu metode untuk pelaksanaan tugas motorik. Oleh karena aktivitas hidup sehari-hari terutama merupakan suatu open tasks, maka seorang penderita stroke lebih baik dilatih untuk melakukan strategi pergerakan umum yang dapat diaplikasikan pada sejumlah lingkungan (Majsak, 1996).

MEDIKORA Vol. V, No 1, April 2009: 118-129 


\section{Strategi terapi}

Tujuan rehabilitasi stroke adalah untuk melatih penderita mengembangkan strategi pergerakan yang bersifat fungsional, responsif terhadap perubahan lingkungan dan mudah diadaptasikan pada àktivitas hidup sehari-hari. Penetapan strategi terapi didasarkan pada

1. Penggunaan pendekatan analitik untuk menganalisa strategi pergerakan, respon postural dan umpan balik yang dibutuhkan untuk timbulnya gerakan yang diinginkan.

2. Menentukan komponen yang hilang dalam kontrol motorik gerakan normal

3. Melakukan latihan dengan memposisikan penderita sebagai active learner (penderita berpartisipasi aktif dalam pergerakan dengan mengembangkan kemampuannya sendiri dalam mengotrol gerakan).

4. Lingkungan harus bersifat mendukung terjadinya kerjasama antara penderita dan terapis serta dibentuk sedemikian rupa agar mendekati lingkungan aktual sehingga dapat meningkatkan kemampuan mentransfer keterampilan motorik yang dipelajari ke dalam situasi kehidupan nyata.

5. Latihan dilakukan dalam konteks aktivitas fungsional, karena selain merupakan suatu gerakan yang bertujuan (meaningful goal - directed actions) juga memfasilitasi proses transfer motor learning ke dalam aktivitas hidup sehari-hari. 


\section{KESIMPULAN}

Program rehabilitasi yang berhasil untuk penderita stroke tergantung pada ketepatan menentukan determinan terjadinya disfungsi pergerakan, penegakan tujuan terapi yang realistik dan pemilihan strategi intervensi yang tepat serta penggunaan prinsipprinsip latihan serta motor learning.

\section{Daftar Pustaka}

Abdersib T, Rehabilitation of patients with completed stroke. Dalam : Kottke FJ, Lehmann JF, penyunting. Krusen's hand book of physical medicine and rehabilitation. Edisi ke 4. Philadelphia: WB Saunders;1990.h. 656-78.

Brandstater ME, Stroke rehabilitation. Dalam : DeLisa JA, Gans $\mathrm{BM}$, penyunting. Rehabilitation medicine principles and practice. Edisi ke 3.Philadelphia : Lippincott Raven;1998.h.1165-89.

Basmajian JV. Therapeutic exercise for stroke patients. Dalam : Basmajian JV \& Wolf SL, penyunting. Therapeutic exercise. Edisi 5. Baltimore : William Wilkins; 1990. h. 207-30

Duncan PW, Badke MB. Therapeutic strategies for rehabilitation of motor deficits. Dalam : Stroke Rehabilitation : The Recovery of Motor Control. Chicago: Year Book Medical Publishers, Inc; 1987.h. 161-95.

PERDOSRI. Konsensus Nasional Rehabilitasi Stroke. Jakarta : PERDOSRI. 2004.

Tse DW. Practice condition and motor learning in individual poststroke : A pilot study comparing random and block practice. London, Ontario: January.1999. p. 2-17.

MEDIKORA Vol. V, No 1, April 2009: 118-129 